ŁUKASZ GAWOR, Politechnika Śląska, Gliwice, Polska Witold Warcholik, Piotr Dolnicki Uniwersytet Pedagogiczny, Kraków, Polska

\title{
Możliwości eksploatacji złóż wtórnych (zwałowisk pogórniczych)jako przykład zmian w sektorze przemysłu wydobywczego
}

\section{Possibilities of exploitation of secondary deposits (post mining dumping grounds) as an example of changes in extractive industry}

\begin{abstract}
Streszczenie: W polskim przemyśle górniczym powstaje średnio ok. $35 \cdot 10^{6} \mathrm{Mg}$ odpadów rocznie. Zwałowiska pogórnicze po eksploatacji węgla kamiennego w Polsce zlokalizowane są w obrębie ponad 250 obiektów, w trzech zagłębiach węglowych: górnośląskim (GZW), dolnośląskim (DZW) i lubelskim (LZW). Z występowaniem zwałowisk pogórniczych wiąże się wiele zagrożeń dla środowiska naturalnego, a także dla mieszkańców terenów z nimi sąsiadujących, co wymaga podjęcia skutecznych środków zapobiegawczych. W artykule, na bazie przeprowadzonych badań terenowych, przedstawiono rozmieszczenie oraz charakterystykę zwałowisk pogórniczych na obszarze Górnośląskiego Zagłębia Węglowego. Omówiono najważniejsze aspekty środowiskowe dotyczące składowania odpadów górniczych. Dokonano oceny technicznych możliwości odzysku węgla ze zwałowisk jako antropogenicznych złóż wtórnych, uzupełnionej ekonomicznym uzasadnieniem odzysku węgla ze zwałowiska pogórniczego. Przedstawiono także uregulowania prawne związane z eksploatacją tych obiektów.
\end{abstract}

\begin{abstract}
Polish coal mining industry produces ca. 35 millions $\mathrm{Mg}$ of mining wastes per year. There are ca. 250 post - mining dumping grounds in Poland, situated in three coal basins: Upper Silesian Coal Basin, Lower Silesian Coal Basin and Lublin Coal Basin. Post - mining dumping grounds may cause serious environmental hazards. Their negative influence on the natural environment, as well as risks posed to the inhabitants, calls for effective preventative measures. In the paper, presented are distribution and characteristics of post - mining dumping grounds in the Upper Silesian Coal Basin. The most important environmental issues connected with disposing of wastes are discussed. Technical possibilities of recovery of coal from waste dumps as anthropogenic secondary deposits are analyzed. An example of economical justification of recovery of coal from post - mining dumping ground is presented. Also mentioned are legal regulations connected with exploitation of waste dumps.
\end{abstract}

Słowa kluczowe: antropogeniczne złoża wtórne; Górnośląskie Zagłębie Węglowe; odpady pogórnicze; zwałowiska pogórnicze

Keywords: anthropogenic secondary deposits; Upper Silesian Coal Basin; mining wastes; post-mining dumping grounds 
WSTEP

Polskie górnictwo węglowe produkuje rocznie ok. $80 \mathrm{mln} \mathrm{Mg} \mathrm{węgla.} \mathrm{Procesom} \mathrm{jego}$ eksploatacji oraz przeróbki towarzyszy skała płonna, stanowiąca odpady pogórnicze. W procesie przeróbki węgla skała (odpad) powstaje w wyniku procesów wzbogacania (odpady płuczkowe), natomiast najdrobniejsze frakcje powstają podczas flotacji węgla. Według różnych źródeł szacuje się, że $1 \mathrm{Mg}$ węgla towarzyszy ok. 0,4-0,5 Mg odpadów. Materiał ten jest deponowany na zwałowiskach pogórniczych lub wykorzystywany w procesach odzysku. W polskim przemyśle górniczym powstaje średnio ok. $35 \cdot 10^{6} \mathrm{Mg}$ odpadów rocznie. Zwałowiska pogórnicze po eksploatacji węgla kamiennego w Polsce zdeponowane są w ponad 250 obiektach i zajmują powierzchnię ponad 4000 ha. Ilość składowanych odpadów szacuje się na 760 mln Mg (www.stat.gov.pl; Szczepańska, Twardowska, 2004).

Złożem antropogenicznym nazywamy sztucznie utworzone nagromadzenie wydobytej lub przetworzonej substancji mineralnej o właściwościach surowca mineralnego. Eksploatacja złóż antropogenicznych (złóż wtórnych) może być przykładem zmian w sektorze przemysłu wydobywczego. Do perspektywicznych złóż antropogenicznych należą m.in. zwałowiska po górnictwie węgla kamiennego. Należy podkreślić, że zrównoważone działania w zakresie odzysku węgla ze zwałowisk są uzasadnione zarówno ekonomicznie, jak i środowiskowo oraz powinny mieć istotne znaczenie dla społeczności lokalnych.

Poniżej przedstawiono wyniki prac zmierzających do określenia przestrzennego rozkładu oraz charakterystyk jakościowych zwałowisk pogórniczych na obszarze Górnośląskiego Zagłębia Węglowego. Badania terenowe, przeprowadzone przez autorów w latach 20132014, podczas których kartowano zwałowiska, uzupełniono analizą aktualnego materiału statystycznego i kartograficznego, pozyskanego przez kontakt z wszystkimi jednostkami administracyjnymi (gminami) i zakładami górniczymi, na terenie których znajdują się omawiane obiekty. W efekcie przeprowadzonych prac dokonano aktualizacji dotychczasowej inwentaryzacji zwałowisk po górnictwie węgla kamiennego (Sikorska-Maykowska, 2001). Dodatkowo, przedstawiono najważniejsze aspekty środowiskowe dotyczące składowania odpadów górniczych oraz dokonano oceny technicznych możliwości pozyskiwania węgla ze zwałowisk, uzupełnionej uregulowaniami prawnymi i ekonomicznym uzasadnieniem odzysku.

\section{ZwaŁowiska Po GÓRnictwie węGla Kamiennego w Polsce}

Zwałowiska odpadów po górnictwie węgla kamiennego w Polsce zlokalizowane są w trzech zagłębiach węglowych: górnośląskim (GZW), dolnośląskim (DZW) i lubelskim (LZW). Najwięcej zwałowisk pogórniczych znajduje się na obszarze Górnośląskiego Zagłębia Węglowego, co wiąże się z największą liczbą zakładów górniczych funkcjonujących zarówno w przeszłości, jak i obecnie na tym terenie. 


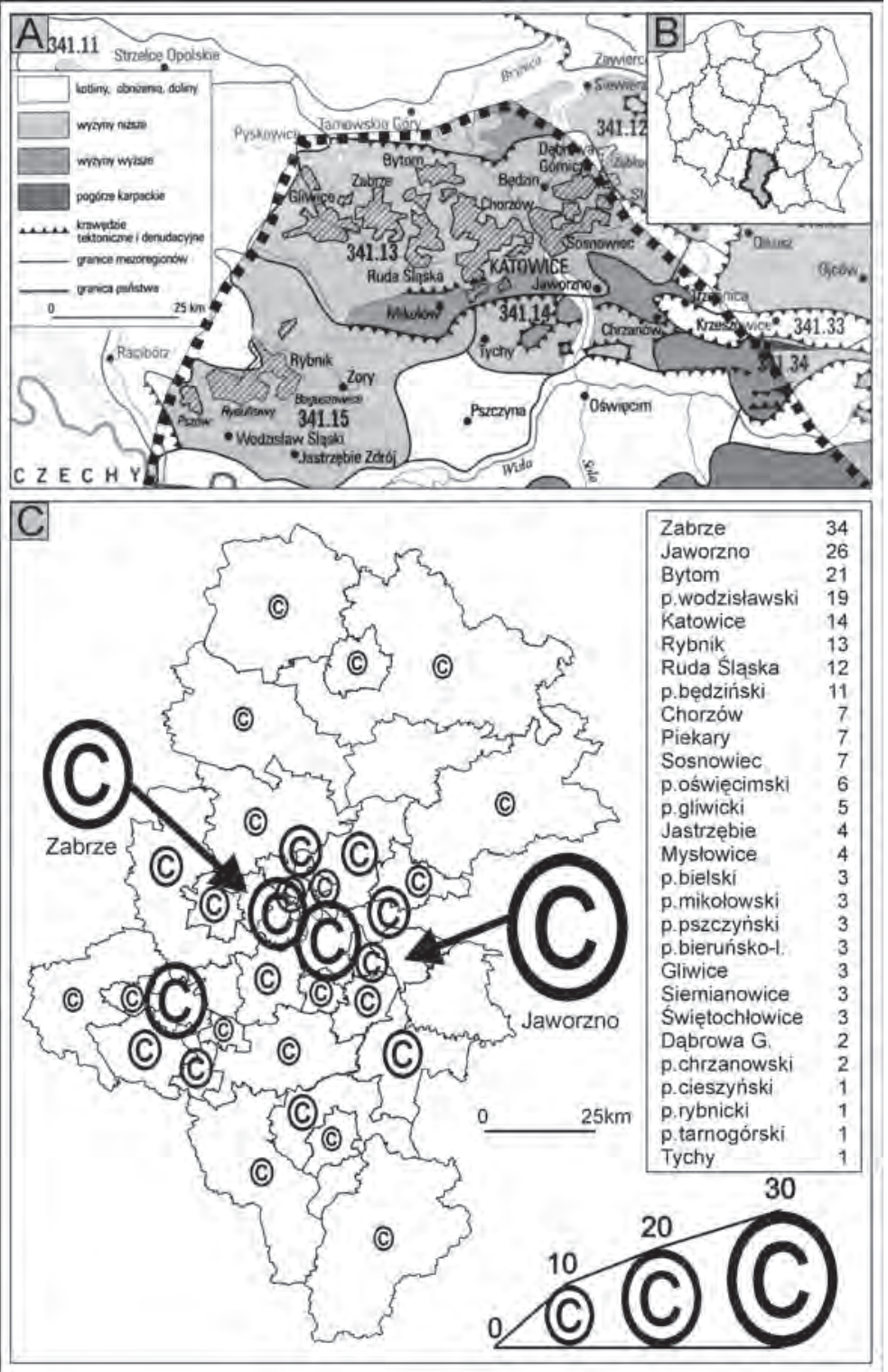

Ryc. 1. Lokalizacja zwałowisk po górnictwie węgla kamiennego na obszarze GZW

A i B - lokalizacja zwałowisk na tle mezoregionów Wyżyny Śląsko-Krakowskiej (za Kondrackim, 1998) i jednostek wojewódzkich w Polsce

C - liczba zwałowisk w obrębie powiatów województwa śląskiego i wybranych powiatów województwa małopolskiego w 2014 roku

Źródło: opracowanie własne

W Górnośląskim Zagłębiu Węglowym zlokalizowanych jest 219 zwałowisk (ryc. 1, tab. 1), zajmujących łącznie powierzchnię ponad 4000 ha. Największe pod względem powierzchni zwałowisko zajmuje ponad 250 ha (Gawor, 2004; Gawor, Main, 2007; Gawor, 2013). 
Najwyższe zwałowiska osiągają wysokość względną powyżej $100 \mathrm{~m}$. W literaturze wyróżniono trzy generacje (typy) zwałowisk pogórniczych, a głównym kryterium podziału jest ich kształt: zwałowiska stożkowe (I), najstarsze, o stromych zboczach i niewielkim stopniu zagęszczenia, odpadów, zwałowiska stołowe (II) w kształcie góry stołowej, których materiał jest zagęszczony oraz zwałowiska krajobrazowe (III), będące obiektami o łagodnych kształtach, wkomponowanych w otaczający krajobraz (Gawor, 2004). Największa koncentracja zwałowisk występuje w centralnej części GZW, w tym m.in. w Zabrzu (34 zwałowiska), Jaworznie (26), Bytomiu (21), Rudzie Śląskiej (12), a także w części południowo-zachodniej GZW, tj. w Rybniku (13 zwałowisk) oraz Jastrzębiu-Zdroju i okolicach (9).

Tab. 1. Liczba zwałowisk po górnictwie węgla kamiennego w gminach obszaru GZW w 2014 roku

\begin{tabular}{|l|l|l|l|l|l|}
\hline Zabrze & 34 & Ruda Śląska & 12 & $\begin{array}{l}\text { Gliwice, Bestwina, Siemianowice, } \\
\text { Swiętochłowice }\end{array}$ & 3 \\
\hline Jaworzno & 26 & $\begin{array}{l}\text { Piekary, Wodzisław, Chorzów, } \\
\text { Sosnowiec }\end{array}$ & 7 & $\begin{array}{l}\text { Laziska Górne., Lędziny, Dąbrowa } \\
\text { Górnicza, Godów }\end{array}$ & 2 \\
\hline Bytom & 21 & Brzeszcze (malopolskie) & 6 & $\begin{array}{l}\text { Bieruń, Czerwionka, Tychy, } \\
\text { Sośniowice, Suszec, Miedźna, } \\
\text { Zebrzydowice, Pszczyna, Lubomia, } \\
\text { Psary, Zbrosławice, Mszana, } \\
\text { Ornontowice, } \\
\text { Libiąż (małopolskie), Trzebinia } \\
\text { (małopolskie) }\end{array}$ & 1 \\
\hline
\end{tabular}

Źródło: opracowanie własne na podstawie przeprowadzonych badań terenowych

Pod względem prawnym większość obiektów jest uznawana za zrekultywowane, jednakże analiza materiałów kartograficznych oraz prace terenowe wykonane przez autorów wykazały, że efektywność rekultywacji jest w bardzo wielu przypadkach niska (brak okrywy roślinnej lub jej występowanie w wersji szczątkowej, słaby rozwój gatunków drzewiastych, erozja powierzchni zwałowisk). Konieczne byłoby wprowadzenie szczegółowych uregulowań prawnych dotyczących rekultywacji biologicznej zwałowisk pogórniczych, a także monitoringu efektów tejże rekultywacji (Gawor, Main, 2007; Gawor, 2011).

W Dolnośląskim Zagłębiu Węglowym zwałowiska zlokalizowane są w okolicy Wałbrzycha i Nowej Rudy. W regionie wałbrzyskim zwałowiska pogórnicze powstawały w latach 1865-1996. Na omawianym obszarze zlokalizowano ich 39. W latach 1960-1996 górnictwo węglowe w Wałbrzychu wyprodukowało ok. $51 \mathrm{mln} \mathrm{Mg}$ odpadów. Całkowita powierzchnia zwałowisk obejmuje ok. 305 ha. Łączna ilość odpadów osiąga $65 \mathrm{mln} \mathrm{m}^{3}$. Największy obiekt ma objętość 23077 tys. m³ a najmniejszy 15 tys. m³. Wysokość zwałowisk waha się od 3 do 105 m, większość form dochodzi do wysokości 15-20 m. Największe powierzchniowo zwałowisko w regionie wałbrzyskim osiąga 50 ha (Wójcik, 2007; Wójcik, 2012). W rejonie Nowej Rudy zlokalizowano dwa zwałowiska powęglowe: zwałowisko przyzakładowe dawnej kopalni Nowa Ruda (4/4, przy szybie Lech 6,6 ha, 2,2 mln t) oraz zwałowisko 7/4 wraz z osadnikami mułowymi (w dzielnicy Nowej Rudy - Słupiec) o powierzchni 35 ha (fot. 1). 


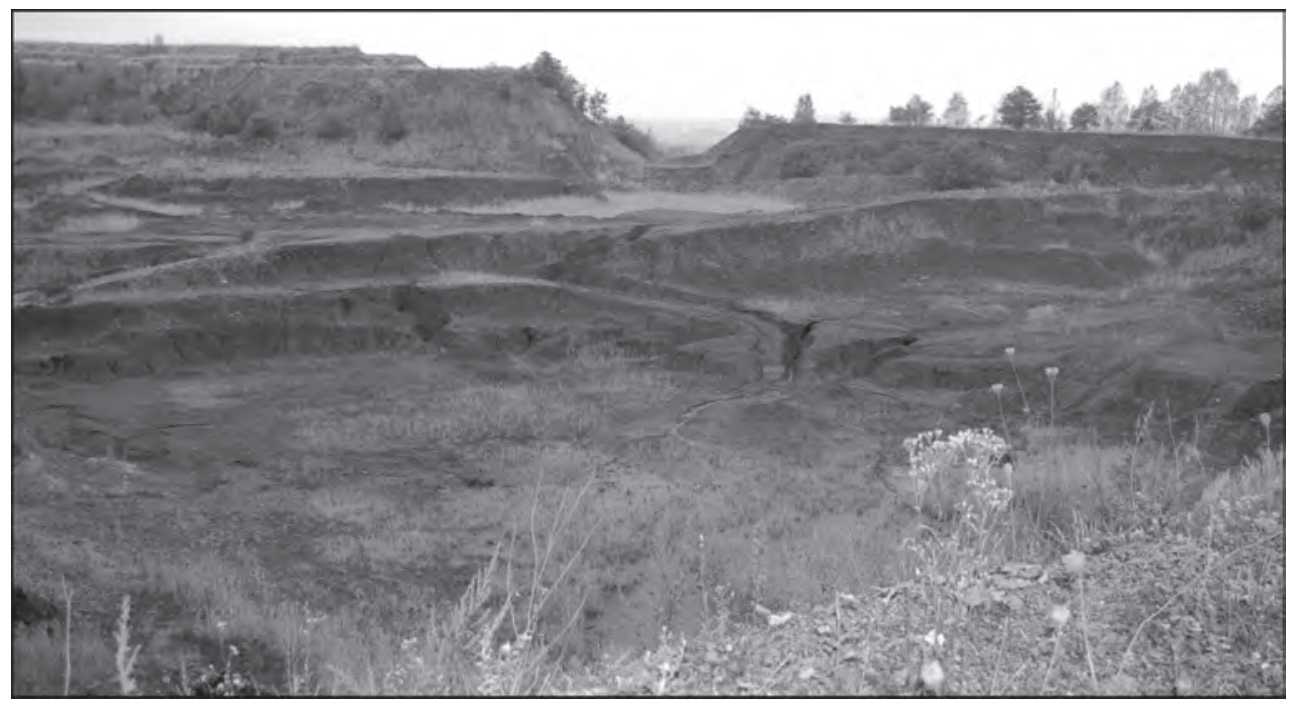

Fot. 1. Zwałowisko w Nowej Rudzie, pole Słupiec (fot. Ł. Gawor)

W Lubelskim Zagłębiu Węglowym znajduje się tylko jedno zwałowisko przyzakładowe KWK Bogdanka, o powierzchni 65 ha, które ma zostać powiększone do powierzchni 88 ha (www.lw.com.pl).

\section{ZAGADNIENIA WPŁYWU ZWAŁOWISK NA ŚRODOWISKO PRZYRODNICZE}

Z występowaniem zwałowisk pogórniczych wiąże się wiele zagrożeń dla środowiska naturalnego. Niekorzystnym zmianom podlega ich stateczność (procesy erozyjne przypominające procesy stokowe na skarpach zwałowisk), do najważniejszych zagrożeń zalicza się zanieczyszczenie wód powierzchniowych i podziemnych.

Wody infiltrujące w obrębie zwałowisk powodują wymywanie łatwo rozpuszczalnych soli, głównie chlorków. Poza tymi związkami dodatkowo wymywane są inne minerały głównie gips oraz węglany. Wietrzenie i utlenianie dotyczy przede wszystkim pirytu $\left(\mathrm{FeS}_{2}\right)$ i zachodzi na odsłoniętych powierzchniach zwałowisk. Utlenianie pirytu wiąże się z zakwaszaniem odpadów karbońskich (pH osiąga wartość 2,5-3) oraz ryzykiem powstawania metali ciężkich.

Wyróżniono trzy fazy procesów hydrochemicznych na zwałowiskach:

- I-w pierwszej fazie następuje wymywanie soli oraz rozpuszczanie siarczanów. Obserwuje się krótkotrwałe obniżenie wartości pH, która jednak ostatecznie kształtuje się na poziomie 7,5-8.

- II - druga faza wietrzenia została wyróżniona jako utlenianie pirytu, które prowadzi do produkcji kwasów wg wzoru: $\mathrm{FeS}_{2}+7 /{ }_{2} \mathrm{O}_{2}+\mathrm{H}_{2} \mathrm{O} \rightarrow \mathrm{Fe}^{2+}+2 \mathrm{SO}_{4}^{2-}+2 \mathrm{H}$. 
- III - w trzeciej fazie wietrzenia, przy wartości pH poniżej 4, może dojść do migracji Fe,

$\mathrm{Mn}, \mathrm{Zn}, \mathrm{Cu}, \mathrm{Pb}$ oraz innych minerałów ciężkich. Przejście między II i III fazą wietrzenia jest uzależnione od dużej zawartości pirytu.

Sposoby przeciwdziałania zanieczyszczeniu wód powierzchniowych w obrębie zwałowisk to budowanie infrastruktury ich odwodnienia oraz zbieranie i odprowadzanie wód do oczyszczalni. Przykładem może być kolektor „Olza”, zbierający wody ze zwałowisk oraz odprowadzający dołowe wody kopalniane w subregionie rybnickim (Labus, Skoczyńska 2005; Twardowska, 1981; Wiggering, 1984).

W składzie petrograficznym zwałowisk odpadów powęglowych dominują iłowce, mułowce, piaskowce, w dalszej kolejności łupki węglowe, może też występować od kilku do kilkunastu procent węgla. Zawartość węgla w odpadach stanowi zagrożenie dla środowiska, ponieważ może dochodzić do samozagrzewania, samozapłonu oraz pożarów zwałowisk (fot. 2). Ze względu na przyczynę powstania wyróżnia się dwa rodzaje pożarów: egzogeniczne, powstające w wyniku działania zewnętrznego źródła temperatury, oraz endogeniczne, będące wynikiem naturalnego niskotemperaturowego procesu utleniania się substancji węglowej lub innej, np. pirytu. Wysoka temperatura i ograniczony dostęp powietrza powodują wytlewanie lub nawet koksowanie, podczas którego następuje termiczny rozkład węgla (piroliza). Inne produkty gazowe powstające podczas procesów samozapłonu i pożarów zwałowisk to: dwutlenek siarki, dwutlenek azotu, węglowodory alifatyczne i aromatyczne, siarkowodór, dwusiarczek węgla (Gawor, Różański, 2012) . Z tego powodu odzysk węgla stanowi działanie ograniczające potencjalny niekorzystny wpływ zwałowisk na środowisko, a także życie i zdrowie ludności zamieszkującej w bezpośrednim sąsiedztwie zwałowisk (Szczepańska, Twardowska, 1999; Gawor, 2011).

\section{UREGULOWANIA PRAWNE I OCENA MOŻLIWOŚCI ODZYSKU WĘGLA ZE ZWALOWISK}

Obowiązująca ustawa - Prawo geologiczne i górnicze - nie definiuje pojęcia złoża antropogenicznego, a pod pojęciem złoża kopaliny należy rozumieć naturalne nagromadzenie minerałów, skał oraz innych substancji, których wydobywanie może przynieść korzyść gospodarczą (ustawa z 9 czerwca 2011 r. - Prawo geologiczne i górnicze, Dz.U. z 2011 roku nr 163, poz. 981, art. 6 ust. 19). W związku z tym poszukiwanie i eksploatacja surowców antropogenicznych nie wymaga uzyskania koncesji.

Naczelna zasada gospodarowania odpadami, zawarta w ustawie z 27 kwietnia 2001 roku o odpadach (Dz.U. z 2001 roku nr 62, poz. 628, art. 5 pkt 2) wymaga ,zapewnienia zgodnego z zasadami ochrony środowiska odzysku", jeżeli nie udało się zapobiec powstawaniu odpadów. Posiadacz odpadów wydobywczych jest zobowiązany do ograniczania negatywnego oddziaływania odpadów wydobywczych na środowisko, życie i zdrowie ludzi, przy uwzględnieniu najlepszych dostępnych technik, o których mowa w art. 3 pkt 10 ustawy z dnia 27 kwietnia 2001 roku - Prawo ochrony środowiska (Dz.U. z 2001 roku nr 62, poz. 627). Posiadacz odpadów wydobywczych jest również zobowiązany „w pierwszej kolejności 
do poddania ich odzyskowi”, a jeżeli z przyczyn technologicznych jest on niemożliwy lub nie jest uzasadniony z przyczyn ekonomicznych, do ich unieszkodliwienia. Ma to nastąpić zgodnie z wymaganiami ochrony środowiska lub programem gospodarowania odpadami wydobywczymi, przy uwzględnieniu najlepszych dostępnych technik, o których mowa w art. 3 pkt 10 prawa ochrony środowiska (Gawor, 2011).

Odzysk węgla z opadów zgodnie z obowiązującymi uregulowaniami prawnymi jest zatem priorytetem, jest on również technologicznie możliwy i ekonomicznie uzasadniony. W związku z powyższym zwałowiska pogórnicze nie tylko mogą, ale powinny być uznane za antropogeniczne złoża wtórne.

Technologie odzysku węgla ze zwałowisk są znane, w przeszłości prowadzono eksploatację m.in. Centralnego Zwałowiska Odpadów Górniczych w Smolnicy (gmina Sośnicowice) i Bukowie (gmina Lubomia). Obecnie prowadzony jest odzysk m.in. na zwałowiskach w Czerwionce (gmina Czerwionka-Leszczyny), Panewnikach (na granicy Mikołowa i Katowic), w Knurowie i Pszowie.

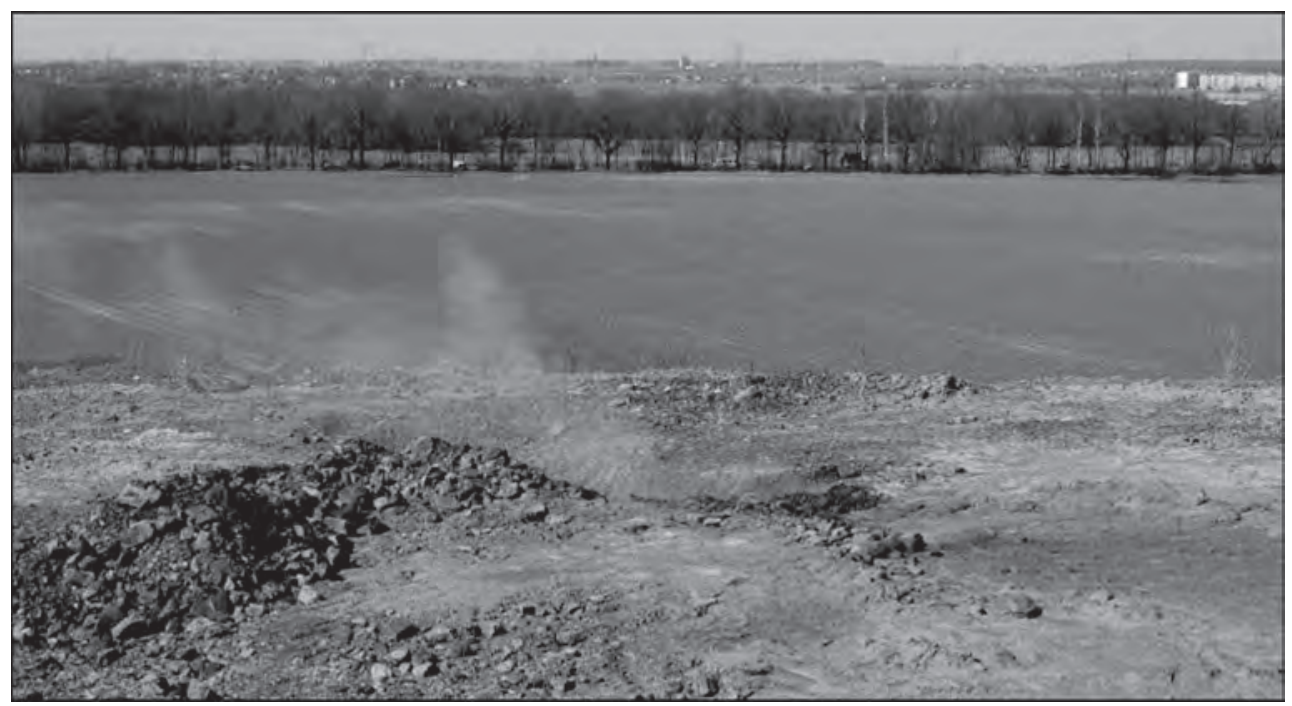

Fot. 2. Zwałowisko 1/R w Zabrzu Mikulczycach - zagrożenia pożarowe (fot. Ł. Gawor)

Instalacje do odzysku węgla z odpadów bazują na procesach stosowanych w zakładach przeróbczych kopalń węgla kamiennego. Wykorzystuje się głównie przeróbkę na mokro z wykorzystaniem cieczy ciężkich. Proces technologiczny obejmuje segregację materiału metodą sitową, na przesiewaczach i sitach stałych, wzbogacanie w hydrocyklonach (np. z wykorzystaniem magnetytu) i odwadnianie na przesiewaczach odwadniających oraz w wirówkach.

Istotne zagadnienie stanowi transport odpadów. Ze względu na negatywne oddziaływanie na środowisko środki transportu ciężkiego (koparki, ładowarki, samochody ciężarowe) ograniczone są do minimum. Odpady są transportowane w większości z wykorzystaniem 
przenośników taśmowych. Najlepszym rozwiązaniem transportowym jest również wykorzystanie bocznicy kolejowej bezpośrednio przy eksploatowanym zwałowisku.

Eksploatacja zwałowisk musi zostać poprzedzona odpowiednim rozpoznaniem materiału odpadowego. W tym celu konieczne jest przeprowadzenie kampanii wiertniczej (wiercenia o siatce minimum jeden odwiert na 1 ha powierzchni), a po pobraniu prób - badania laboratoryjne. Obejmują one przygotowanie prób, oznaczenie zawartości popiołu, siarki całkowitej, wilgoci, wartości opałowej i ciepła spalania we wszystkich pobranych próbach. Następnie przeprowadza się analizę densymetryczną w wytypowanych próbach o najniższych wartościach zawartości popiołu, a w uzyskanych frakcjach ponownie oznacza się wymienione powyżej wskaźniki. Na podstawie wyników badań można oszacować potencjalny uzysk węgla oraz zaprojektować instalację o określonej wydajności.

Inwestycja powinna być poprzedzona studium wykonalności oraz analizą ekonomiczną, uwzględniającą objętość zdeponowanego materiału, uzysk, zakładany czas funkcjonowania zakładu przeróbczego oraz uwarunkowania logistyczno-transportowe (media - głównie woda, rodzaj i liczba środków transportu). Przykładowy zakład przeróbczy przedstawiono na fot. 3.

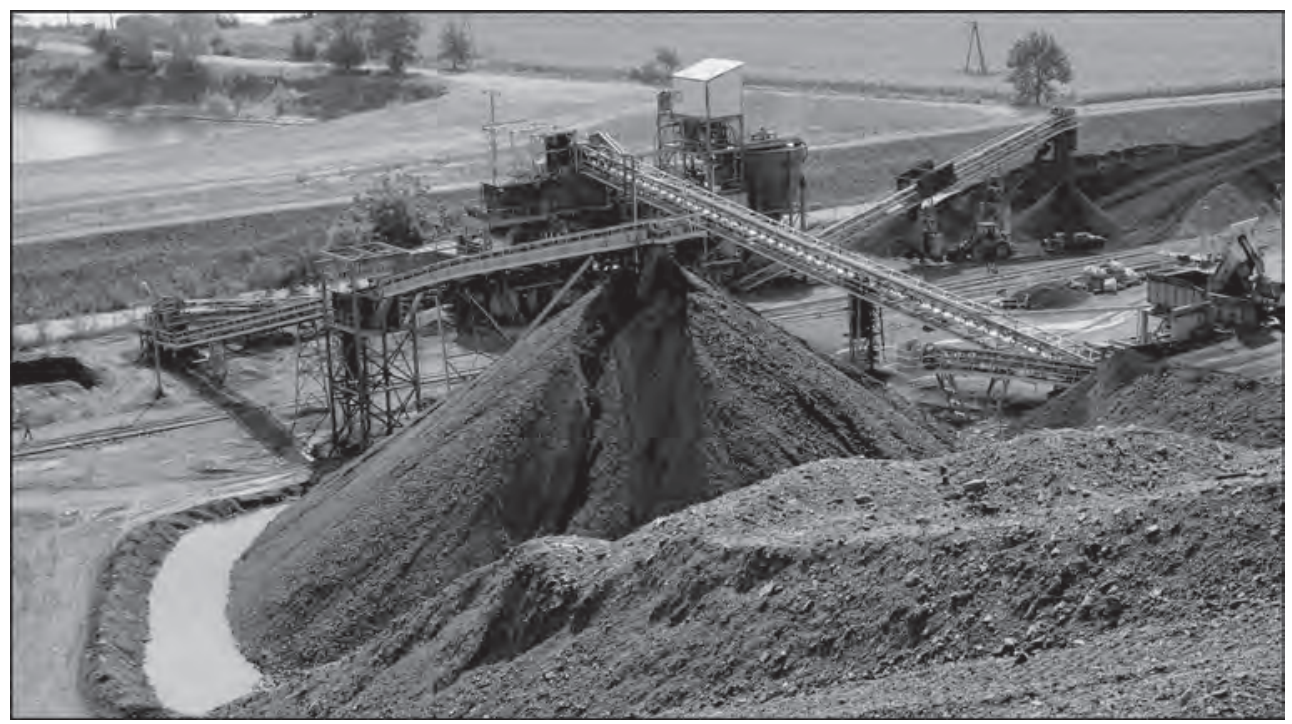

Fot. 3. Zakład przeróbczy przy zwałowisku po górnictwie węgla kamiennego (fot. M. Redoute)

Odzysk węgla ze zwałowisk wiąże się z koniecznością późniejszej rekultywacji obiektu. Do jej przeprowadzenia wykorzystuje się materiał odpadowy wcześniej przetworzony w zakładzie przeróbczym. Ogranicza to koszty pozyskiwania dodatkowych materiałów do tworzenia okrywy rekultywacyjnej (Strzyszcz, 2004).

Próbę analizy ekonomicznej odzysku węgla ze zwałowisk polskich zagłębi górniczych przeprowadzono z uwzględnieniem łącznej masy odpadów na poziomie ok. $800 \mathrm{mln} \mathrm{t}$, wynikającej z sumarycznych ponad 4000 ha powierzchni skartowanych 259 obiektów. Przy 
założeniu, że ok. 10\% zwałowisk zawiera materiał już przepalony (informacje pozyskane na podstawie badań terenowych), ok. 230 obiektów nadaje się do potencjalnego odzysku. Średni uzysk węgla to $8 \%$ (uśrednione dane z zakładów przeróbczych, dotyczące zwałowisk eksploatowanych w przeszłości - Michel Redoute, informacja ustna), co przekłada się na całościową możliwość produkcji węgla ze zwałowisk na poziomie $60 \mathrm{mln} \mathrm{Mg}$. Przy założeniu średniej ceny węgla 500 zł za tonę można wyszacować potencjalny przychód rzędu 30 mld zł. Wartość ta jest porównywalna z roczną produkcją węgla kamiennego w polskim górnictwie. W przypadku poszczególnych zakładów przeróbczych prowadzących odzysk węgla w przeszłości i obecnie działalność każdego z nich była opłacalna ekonomicznie. Kolejne podmioty wciąż prowadzą nowe projekty dotyczące odzysku węgla ze zwałowisk (m.in. Haldex SA, Mo-BRUK SA).

\section{WNIOSKI}

Analiza rozmieszczenia i charakterystyk zwałowisk pogórniczych na obszarze Górnośląskiego Zagłębia Węglowego, z uwzględnieniem uregulowań prawnych dotyczących eksploatacji tych obiektów, a także najważniejszych aspektów środowiskowych związanych z ze składowaniem, pozwoliła na wyciągnięcie poniższych wniosków:

- istnieje potrzeba i konieczność uznania zwałowisk po górnictwie węgla kamiennego za antropogeniczne złoża wtórne,

- eksploatacja węgla ze zwałowisk zapobiega występowaniu zagrożeń dla środowiska W związku z samozapłonem materiału odpadowego oraz pożarami,

- technologie odzysku węgla wykorzystują procesy przeróbcze stosowane w kopalniach i są ekonomicznie uzasadnione,

- bezpieczna eksploatacja zwałowisk pogórniczych musi uwzględniać odpowiednie uregulowania prawne,

- możliwość odzysku węgla może dotyczyć ok. 230 obiektów na obszarze GZW, DZW i LZW, a całościowa potencjalna produkcja może być porównywalna z rocznym wydobyciem węgla kamiennego w polskim górnictwie,

- eksploatacja zwałowisk stanowi rozszerzenie możliwości eksploatacji węgla kamiennego w Polsce i może być przykładem zmian w przemyśle wydobywczym.

\section{Literatura \\ References}

Gawor, Ł. (2004). Wybrane zagadnienia sozologii górniczej w Zagłębiu Ruhry i Górnośląskim Zagłębiu Węglowym (GZW) na przyktadzie zwałowisk pogórniczych - studium porównawcze. Gliwice: Zeszyty Naukowe Politechniki Śląskiej, Górnictwo, 260, 97-108.

Gawor, Ł. (2011). Der Einfluss von Rechtsvorschriften auf Rekultivierung und Folgenutzung von Bergehalden am Beispiel des Oberschlesischen Steinkohlebeckens und des Ruhrgebietes. Gliwice: Wydawnictwo Politechniki Śląskiej, 72. 
Gawor, Ł. (2013). Environmental impact of coal-mining wastes in Poland with regard to legal regulations. W: J. Kortnik (red.). Proceedings of 14th conference with international participation "Waste Management - GzO 13”. Krsko, ISBN 978-961-6047-79-1, 102-108.

Gawor, Ł., Main, M. (2007). Ausgewählte Umweltprobleme im Ruhrgebiet und im Oberschlesischen Kohlenbezirk $(G Z W)$ am Beispiel von Bergehalden. Veröffentlichungen von der 16. Tagung für Ingeniuergeologie und vom Forum Junge Ingenieurgeologen. Bochum, 07. bis 10. März 2007, 95-103.

Gawor, Ł., Różański, Z. (2012). Wybrane problemy rekultywacji, zagospodarowania oraz oddziaływania na środowisko zwałowisk pogórniczych w odniesieniu do uregulowań prawnych. W: Materiały z konferencji „Factum est factum” zorganizowanej przez Urząd Miejski w Bytomiu 16 stycznia 2012 roku, 15-16.

Kondracki, J. (1998). Geografia regionalna Polski. Warszawa: Wydawnictwo Naukowe PWN.

Labus, K., Skoczyńska, S. (2005). Wpływ reaktywnego dolomitu na odczyn wód odciekowych składowiska Smolnica. Zeszyty Naukowe Politechniki Śląskiej, nr 1690, Górnictwo, z. 267, 147-154.

Sikorska-Maykowska, M. (2001). Waloryzacja środowiska przyrodniczego i identyfikacja jego zagrożeń na terenie województwa śląskiego. Warszawa: Państwowy Instytut Geologiczny i Urząd Marszałkowski Województwa Śląskiego.

Strzyszcz, Z. (2004). Ocena przydatności i zasady stosowania różnorodnych odpadów do rekultywacji zwałowisk oraz terenów zdegradowanych działalnością przemysłową. Prace i Studia, 60, 82. Zabrze: Instytut Podstaw Inżynierii Środowiska PAN.

Szczepańska, J., Twardowska, I. (1999). Distribution and environmental impact of coal mining wastes in Upper Silesia, Poland. Environ. Geol., 38, 3, 249-258.

Szczepańska, J., Twardowska, I. (2004). Mining waste. W: I. Twardowska et al. Solid waste: assessment, monitoring and remediation. Amsterdam: Elsevier, 319-386.

Twardowska, I. (1981). Mechanizm i dynamika ługowania odpadów karbońskich na zwałowiskach. Prace i Studia, 25. Zabrze: Instytut Podstaw Inżynierii Środowiska PAN.

Wiggering, H. (1984). Mechanismen bei der Verwitterung aufgehaldeter Sedimente (Berge) des Oberkarbons, Dissertation. Universitäts-Gesamthochschule Essen, 228.

Wójcik, J. (1993). Przeobrażenia ukształtowania powierzchni ziemi pod wplywem górnictwa w rejonie Wałbrzycha. Wrocław: Acta Universitatis Wratislaviensis, 1557, Studia Geograficzne, 59, 5-145.

Wójcik, J. (2007). Rekultywacja hałd na terenach górniczych wałbrzyskich kopalń węgla kamiennego w latach 1960-2005. Przegląd Górniczy, 63 (3), 23-28.

Wójcik, J. (2012). Wałbrzyskie hałdy i osadniki kopalniane jako źródło surowców wtórnych - wstępne wyniki inwentaryzacji. Przegląd Geologiczny, 60, 4, 212-219.

Lukasz Gawor, adiunkt, doktor nauk technicznych w dyscyplinie górnictwo i geologia inżynierska, mgr geografii, specjalność: kształtowanie i ochrona środowiska. Zainteresowania naukowe: sozologia górnicza, przepisy prawne dotyczące rekultywacji, rekultywacja i zagospodarowanie zwałowisk pogórniczych, geoturystyka. Inne zainteresowania: turystyka wysokogórska, wyprawy polarne, bieganie, narciarstwo biegowe.

Lukasz Gawor, holds a Ph.D. title and is an assistant professor at the Silesian University of Technology, in the Institute of Applied Geology. His academic interests include: mining sozology; legal regulations regarding recultivation; recultivating and using post mining dumping grounds; geotourism. His other interests include: high mountain tourism; polar expeditions; running; ski running.

Witold Warcholik, doktor nauk o Ziemi, inżynier geodezji, pracownik Zakładu Turystyki i Badań Regionalnych Instytutu Geografii Uniwersytetu Pedagogicznego w Krakowie. Autor publikacji z zakresu turystyki, geomorfologii, kartografii i GIS. Miłośnik Krakowa, licencjonowany przewodnik miejski, pilot wycieczek, a w czasie wolnym biegacz, entuzjasta turystyki górskiej i fotografii.

Witold Warcholik, holds a Ph.D. title in Earth Sciences and an engineer's degree in geodesy. He is currently employed at the Department of Tourism and Regional Studies at the Pedagogical University 
of Cracow. He is the author of several publications on tourism, geomorphology, cartography and GIS, an avid Cracow fan, licensed Cracow city guide and a tour guide. Moreover, he is a marathon runner, mountaineering enthusiast, and a photographer.

Piotr Dolnicki, doktor nauk o Ziemi, pracownik Zakładu Turystyki i Badań Regionalnych Instytutu Geografii Uniwersytetu Pedagogicznego w Krakowie. Zainteresowania naukowe: geomorfologia, badania polarne, turystyka w obszarach polarnych.

Piotr Dolnicki, holds a Ph.D. title in Earth Sciences. He is currently employed at the Department of Tourism and Regional Studies at the Pedagogical University of Cracow. His academic interests include: geomorphology; polar research; tourism in polar regions.

\section{Adres/address:}

Politechnika Śląska

Instytut Geologii Stosowanej

ul. Akademicka 2, 44-100 Gliwice, Polska

e-mail: lukasz.gawor@polsl.pl

Uniwersytet Pedagogiczny w Krakowie

Instytut Geografii

Zakład Turystyki i Badań Regionalnych

ul. Podchorążych 2, 30-084 Kraków, Polska

e-mail: warwitek@gmail.com

e-mail: dolnicki@up.krakow.pl 